ネルギー巾の狭いX線スペクトルを発生することができ る.すなわち近似的に単色X線と仮定するならば, 被写 体に対する線吸収係数が一定值なので，入射したX線強 度と被写体を透過した後のX線強度を測定することによ り，被写体の厚みを計算することができる，本研究では FCRの直線階調（ポジフィルム）を用い, フィルム濃度 をマイクロデンシトメータで測定することによりX線強 度を求める方式を採用した。実験では水中に造影剤（イ ソペーク 280）を噴射し，これの相対濃度分布を測定し， 良好な結果を得ることができた。

文献 H. Isobe, E. Sato, T. Yanagisawa, SPIE 832 (1987) to be published.

\section{8. 臨床用高出カフラッシュ X線装置の動作特性}

岩手医大・RI ○及川昭弘 岩手医大・中放 秋津武志 岩手医大・放科 柳沢 融 岩手医大・物理 佐藤英一・磯部 寛 北斗精機(侏) 鈴木勁一郎 東北大・中放 有馬宏寧

8 本の同軸ケーブルよりなる低インピーダンス放電回 路を有する臨床用高出力フラッシュX線装置の構造につ いては昨年報告した通りである．本研究ではこの装置を より有効に臨床へ応用するために, X線特性（出力波形, 線質, 実効焦点径) の測定とディレイ装置による撮影法 を検討した. 出力波形の测定には PIN ダイオード, 線質 測定には強度減弱曲線法, 実効焦点測定にはピンホール カメラ法を採用した。本発表ではこれら基礎デー夕を他 の高出力装置のものと比較, 検討する. またX線特性の 調整とディレイ装置により得られたX線画像についても 報告する。

文献 H. Isobe, E. Sato, E, Tanifuji, T. Fujiyama, S. Sato, Jpn. J. Med. Imaging and Information Sci., 3 (1986) 1 .

19. 新スペクトル関数によるフラッシュ X線のスペクト ル分布解析と応用

$$
\begin{array}{r}
\text { 岩手医大・中放 O秋津武志 } \\
\text { 岩手医大・R I 及川昭弘 } \\
\text { 岩手医大・放科 柳沢 融 } \\
\text { 岩手医大・物理 } \\
\text { 川崎 敏・佐藤英一・礎部 寛 } \\
\text { 東北大・医短放 小原春雄・太田 温 } \\
\text { 東北大・中放 有馬宏寧 } \\
\text { 富士メディカルシステム侏) 相沢芳則 }
\end{array}
$$

線源にフィルタを挿入しない場合でのフラッシュX線
(FX) のスペクトルは一般に医療で用いている熱陰極装 置のものと比較して軟成分が非常に多い. したがってス ペクトルの強度ピークはかなり低エネルギー側にある場 合が多い.またフィル夕の捙入によってはピークが急に 高エネルギー側に移動する。ここで Kramerのスペクト ル関数（スムースラインスペクトル）は高エネルギー側 にピークのあるスペクトル分布に適しているので, FX のスペクトル解析には不適当である.したがって本研究 では FXや熱陰極X線のスペクトル分布の双方に適する スペクトル関数を導出し, 強度減弱データと最少自乗誤 差法を用いて解析した．解析に用いた装置は基礎研究用 として試作した低エネルギー高出力型装置である．解析 結果より, 本装置では強度ピークの移動, エネルギー巾 の調整が可能であることが分かり，金属フィルタを用い たエネルギーサブトラクション像の作成や三次元的画像 解析に有用であることが分かった。

文献 E. Sato, H. Isobe, T. Yanagisawa, Annual Report of Iwate Medical University, School of Liberal Arts and Sciences, 21 (1986) 17.

20. 連続照射型フラッシュ X線装置の改良と動作特性 岩手医大・佐藤英一・川崎 敏・磯部 寛 岩手医大・中放 秋津武志
岩手医大 - R I 及川昭弘
岩手医大 - 放科 柳沢 融
東北大 - 中放 有馬宏寧
東北大 - 医短放 清野 浩

単一管を用いた可変エネルギー連続照射型フラッシュ $\mathrm{X}$ 線（FX）装置の構造については昨年報告した. FX 装 置は瞬間に10 kA 以上のインパルス大電流が流れるので これに伴なうノイズシールドが必要となった。本研究で はパルサ回路の一部を改造し，ノイズ発生源にシールド を施した。 また光駆動型のインパルススイッチングシス テムも大巾に改良し，ノイズに強い方式を採用した。

出力波形の測定では PIN ダイオードを用い, 管電流に よる可視光, 同エネルギーでの連続照射 ( 2 連続), 可変 エネルギーでの連続照射特性を測定した。

文献 E.Sato, H. Isobe, T. Yanagisawa, F. Hoshino, SPIE 693, (1986) 33.

\section{1. 多重管型フラッシュ X線装置の試作}

岩手医大・物理 ○佐藤英一・川崎 敏 $\cdot$ 谷藤栄子 佐藤早苗・磯部 寛 岩手医大・中放 秋津武志 岩手医大・R I 及川昭弘 